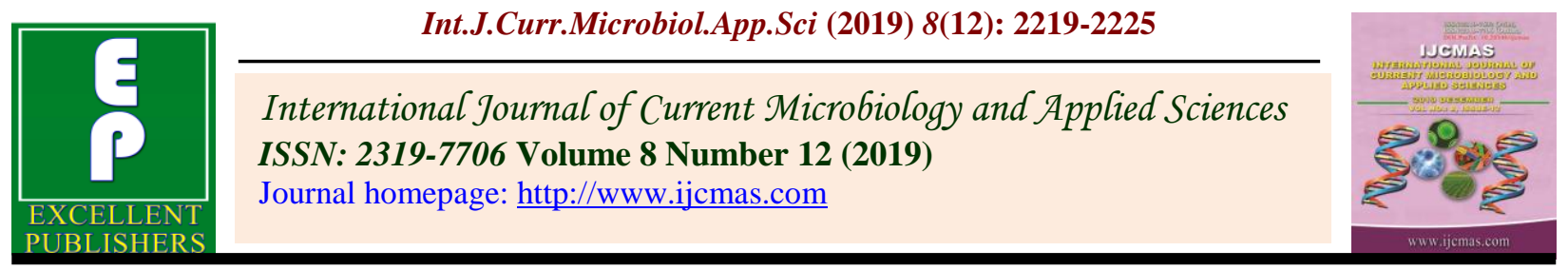

Original Research Article

https://doi.org/10.20546/ijcmas.2019.812.264

\title{
Studies on the Effect of Planting Dates on Growth, Yield Components and Quality of Red Cabbage (Brassica oleracea var. capitata f. rubra)
}

\author{
Abhilash Kavalgi*, R. Rajyalakshmi, K. Uma Jyothi and K. Uma Krishna \\ Dr. YSR Horticultural University, Venkataramannagudem, Tadepalligudem - 534 101, \\ Andhra Pradesh, India \\ *Corresponding author
}

\section{Keywords}

Red cabbage,

Planting dates,

Growth, Yield

components and quality

\section{Article Info}

Accepted:

17 November 2019

Available Online:

10 December 2019

\section{A B S T R A C T}

The investigation entitled "Studies on the effect of planting dates on growth, yield and quality of red cabbage (Brassica oleracea var. capitata f. rubra)" was carried out in Rabi season 2018-2019 at Mango Research Station, Nuzvid, Krishna Dist. (A.P.). Study included three levels of planting dates $\left(30^{\text {th }}\right.$ September, $15^{\text {th }}$ and $30^{\text {th }}$ October) each replicated thrice in FRBD. Planting dates significantly influenced the growth, yield and quality parameters at all the growth stages. Among all the treatments, significantly highest plant height $(34.32 \mathrm{~cm})$, plant spread $(50.46 \mathrm{~cm})$ and number of heading leaves per plant (21.49) recorded at final harvest. Among yield and yield attributing characters maximum head circumference $(46.72 \mathrm{~cm})$, head length $(16.73 \mathrm{~cm})$, head volume $(859.58 \mathrm{cc})$, head compactness $(0.51)$, head weight $(551 \mathrm{~g})$, head yield per plot $(44.10 \mathrm{~kg})$, Estimated yield $\left(338.83 \mathrm{q} \mathrm{ha} \mathrm{h}^{-1}\right)$ and dry matter production (11.24\%) with minimum days to head initiation (47.01days) and head harvest (81.30days) were recorded by $15^{\text {th }}$ October planting date $\left(\mathrm{D}_{2}\right)$ and the same was also maintained best quality with respect to anthocyanin content (118.83 mg/100g), ascorbic acid content (37.68 mg/100g) and TSS $\left(8.54^{\circ}\right.$ Brix).

\section{Introduction}

Red cabbage (Brassica oleracea var. capitata f. rubra) is also known as purple cabbage or red kraut. It is an important fancy and highly nutritive exotic vegetable. It belongs to the family brassicaceae and comes under the subgroup rubra of cabbage (Brassica oleracea var. capitata L.). It is having chromosome number $2 n=2 X=18$. Red cabbage is a native crop in the Mediterranean region of Europe and now grows all over the world as a fresh market vegetable. Red cabbage synthesized and accumulated anthocyanin at all the developmental stages of vegetative growth (Yuan, 2009). It is a rich source of anthocyanin, proteins, fats and minerals like calcium, phosphorus, potassium, sulphur etc. and vitamins viz. $A, B_{1}, B_{2}$ and $C$. Red cabbage distinguished by the presence of 
exceptional health enhancing properties like anticancer properties due to the presence of Indole-3-Carbinol and many beneficial sensory traits, which has become more and more important in recent years (Wojciechowska et al., 2007). In India, cabbage including red cabbage is cultivated in an area of 4.03 lakh hectares producing 91.92 lakh metric tonnes (NHB, 2019).

It is a cool season crop and widely grown in temperate and subtropical region of India. The transition from vegetative to reproductive growth is triggered by temperature. The optimum temperature for growth is $15-18^{\circ} \mathrm{C}$. It can tolerate freezing temperatures but is less tolerant to high temperatures (More, 2006). Very few studies on the growth and yield of red cabbage have been carried out in our country. Therefore, the study of cultivation practices with respect to suitable planting dates is a pre-requisite for any new crop assessment to achieve more returns per unit area. Since, red cabbage crop has been introduced recently in our country there is a need to standardize the planting dates to suit the local conditions.

\section{Materials and Methods}

An investigation entitled "Studies on the effect of planting dates on growth, yield and quality of red cabbage (Brassica oleracea var. capitata f. rubra)" was carried out during rabi season, 2018-2019 at MRS, Nuzvid, Krishna district (A.P.). The location falls under Agroclimatic zone-10, east coastal plain and hills (Krishna-Godavari zone) with an average rainfall of $900 \mathrm{~mm}$, located at an altitude of 34 m (112 feet) above mean sea level. The location is geographically situated at $16^{\circ} 83^{\prime} \mathrm{N}$ latitude and $81^{\circ} 5^{\prime} \mathrm{E}$ longitude. It experiences hot humid summer and mild winter climate. Study included three levels of planting dates $\left(30^{\text {th }}\right.$ September, $15^{\text {th }}$ and $30^{\text {th }}$ October) each replicated thrice in FRBD. The observations were recorded on various growth, yield and quality parameters.

The data obtained in respect to all the characters viz., plant height $(\mathrm{cm})$, plant spread $(\mathrm{cm})$, number of heading leaves per plant, number of days to head initiation (days), number of days to head harvest (days), head circumference $(\mathrm{cm})$, head length $(\mathrm{cm})$, head volume (cc), head compactness, head weight $(\mathrm{g})$, head yield per plot $(\mathrm{kg})$, head yield per hectare (q), dry matter production (\%), anthocynine content (mg $\left.100 \mathrm{~g}^{-1}\right)$, ascorbic acid (mg $\left.100 \mathrm{~g}^{-1}\right)$ and TSS ( ${ }^{\circ}$ Brix) was subjected to the statistical analysis. The data were analyzed by the methods outlined by Panse and Sukhatme (1985) using the mean values of five random plants in each replication from all treatment to find out the significance of planting dates.

\section{Results and Discussion}

\section{Growth parameters}

\section{Plant height $(\mathrm{cm})$, plant spread $(\mathrm{cm})$ and number of heading leaves per plant}

It was observed that significantly highest plant height $(32.32 \mathrm{~cm})$, plant spread $(50.46 \mathrm{~cm})$ and number of heading leaves per plant (21.49) was observed by $15^{\text {th }}$ October planting. However, the minimum plant height $(26.95 \mathrm{~cm})$, plant spread $(38.37 \mathrm{~cm})$ and number of heading leaves per plant (17.26) was recorded with the $30^{\text {th }}$ September planting (Table 1). These above results are indicating the influence of planting dates on all growth parameters. The fluctuation in temperature was the main reason for increase and decrease in growth parameters in red cabbage might be due to favourable climatic conditions available during growth period. Similar results under different climatic conditions were reported in broccoli (Getachew et al., 2016 and Kanase et al., 2018) for plant height; With respect to 
plant spread $(\mathrm{cm})$, similar results were observed in broccoli (Vinod et al., 2017; Kanase et al., 2018), whereas the results were in line with findings by Ullah et al., 2013 in cabbage for number of heading leaves per plant.

\section{Number of days taken to head initiation and head harvest (days)}

The minimum number of days taken to head initiation (47.01 days) and number of days taken to harvest (81.30 days) was recorded with $15^{\text {th }}$ October planting which was significantly superior to $30^{\text {th }}$ October planting with 53.19 and 90.95days to head initiation and harvest, respectively. Whereas the maximum number of days taken to head initiation (59.77 days) and number of days taken to head harvest (101.22 days) was recorded with $30^{\text {th }}$ September planting (Table. 1). Significantly minimum number of days to head initiation and harvest was might be due to favourable climatic conditions available during growth period which enhanced early head initiation and head harvest. The increase in number of days to head initiation and head harvest might be due to the fluctuation and high temperatures prevailing during growth period which resulted in delayed head formation. These findings are in accordance with broccoli (Vipul et al., 2017 and Kanase et al., 2018).

\section{Yield and yield attributing parameters}

\section{Head circumference $(\mathrm{cm})$ and head length (cm)}

Significantly superior head circumference $(46.72 \mathrm{~cm})$ and head length $(16.73 \mathrm{~cm})$ was recorded with $15^{\text {th }}$ October planting, followed by $30^{\text {th }}$ October planting date $\left(\mathrm{D}_{3}\right)$ with $(41.04$ $\mathrm{cm})$ and head length $(14.79 \mathrm{~cm})$, whereas the minimum head circumference $(35.27 \mathrm{~cm})$ and head length $(11.18 \mathrm{~cm})$ was recorded with $30^{\text {th }}$ September planting (Table 2). These variations might be due to the favorable climatic conditions prevailing during the head formation stage. The results were in collaboration with findings obtained in cabbage (Lavanya et al., 2014) and broccoli (Shapla et al., 2014) for head circumference, whereas, in cabbage (Singh et al., 2010), Broccoli (Abd, 2008; Vinodet al., 2017) for head length.

\section{Head volume (cc) and Head compactness}

It was observed that head volume and head compactness differed significantly with planting dates in red cabbage. The highest head volume $(859.58 \mathrm{cc})$ and head compactness $(0.53)$ was recorded with $15^{\text {th }}$ October, whereas the minimum head volume (810.41 cc) and head compactness (0.83) was recorded with $30^{\text {th }}$ September planting (Table. 2 ). The increase in metabolites production due to favourable climate condition attributed to increase in plant growth, it might also be influenced the increase in head volume and compactness. Similar results have been reviled in cabbage by Abed et al., (2015) and in broccoli by Kanase et al., (2018) for head volume with respect to head compactness, Similar findings have been reported by Singh et al., (2010) in cabbage and by Abd (2008) in broccoli.

\section{Head weight (g), head yield per plot $\left(\mathrm{kg} / 12.87 \mathrm{~m}^{2}\right)$}

The data on head weight and head yield per plot revealed significant differences among different planting dates. Significantly higher head weight $(551 \mathrm{~g})$ and head yield per plot $(44.10 \mathrm{~kg})$ was recorded with $15^{\text {th }}$ October planting, whereas the $30^{\text {th }}$ September planting recorded lowest head weight (447 g) and head yield per plot $(35.74 \mathrm{~kg})$ (Table 3$)$. 
Table.1 Effect of planting dates on growth parameters of red cabbage

\begin{tabular}{|c|c|c|c|c|c|}
\hline Treatment & $\begin{array}{c}\text { Plant } \\
\text { height } \\
(\mathrm{cm}) \\
\text { at final } \\
\text { harvest }\end{array}$ & $\begin{array}{l}\text { Plant } \\
\text { spread } \\
(\mathrm{cm}) \\
\text { at final } \\
\text { harvest }\end{array}$ & $\begin{array}{c}\text { No. of } \\
\text { heading } \\
\text { leaves } \\
\text { plant }^{-1}\end{array}$ & $\begin{array}{c}\text { No. of days } \\
\text { to head } \\
\text { initiation } \\
\text { (days) }\end{array}$ & $\begin{array}{l}\text { No. of days } \\
\text { to head } \\
\text { harvest } \\
\text { (days) }\end{array}$ \\
\hline D1: $30^{\text {th }}$ September & 26.95 & 38.37 & 17.26 & 59.77 & 101.22 \\
\hline D2: $15^{\text {th }}$ October & 33.32 & 50.46 & 21.49 & 47.01 & 81.30 \\
\hline D3: $30^{\text {th }}$ October & 30.18 & 44.54 & 19.09 & 53.19 & 90.95 \\
\hline SEm \pm & 0.898 & 1.792 & 0.240 & 0.712 & 2.950 \\
\hline CD@ $9 \%$ & 2.651 & 5.289 & 0.708 & 2.102 & 8.708 \\
\hline
\end{tabular}

Table.2 Effect of planting dates on yield attributing parameters of red cabbage

\begin{tabular}{|c|c|c|c|c|}
\hline Treatment & $\begin{array}{c}\text { Head } \\
\text { circumference } \\
(\mathbf{c m})\end{array}$ & $\begin{array}{c}\text { Head } \\
\text { length } \\
(\mathbf{c m})\end{array}$ & $\begin{array}{c}\text { Head } \\
\text { volume } \\
(\mathbf{c c})\end{array}$ & $\begin{array}{c}\text { Head } \\
\text { compactness }\end{array}$ \\
\hline D1: $\mathbf{3 0}^{\text {th }}$ September & 35.27 & 11.18 & 810.41 & 0.83 \\
\hline D2: $\mathbf{1 5}^{\text {th }}$ October & 46.72 & 16.73 & 859.58 & 0.53 \\
\hline D3: 30 $\mathbf{3 0}^{\text {th }}$ October & 41.04 & 14.79 & 835.41 & 0.58 \\
\hline SEm \pm & 1.420 & 0.334 & 6.669 & 0.035 \\
\hline CD @ 5\% & 4.192 & 0.985 & 19.685 & 0.101 \\
\hline
\end{tabular}

Table.3 Effect of planting dates on yield parameters of red cabbage

\begin{tabular}{|c|c|c|c|c|}
\hline Treatment & $\begin{array}{c}\text { Head } \\
\text { weight } \\
\text { (g) }\end{array}$ & $\begin{array}{c}\text { Head } \\
\text { yield plot } \\
\left(\mathrm{kg} / \mathbf{1 2 . 8 7 m ^ { 2 }}\right)\end{array}$ & $\begin{array}{c}\text { Estimated } \\
\text { yield per } \\
\text { hectare }(q)\end{array}$ & $\begin{array}{l}\text { Dry matter } \\
\text { production } \\
\qquad(\%)\end{array}$ \\
\hline D1: $30^{\text {th }}$ September & 447 & 35.74 & 277.70 & 9.51 \\
\hline D2: $15^{\text {th }}$ October & 551 & 44.10 & 338.83 & 11.24 \\
\hline D3: $30^{\text {th }}$ October & 495 & 39.62 & 307.84 & 10.38 \\
\hline SEm \pm & 9.071 & 0.725 & 5.358 & 0.025 \\
\hline CD@ $5 \%$ & 26.604 & 2.140 & 15.815 & 0.073 \\
\hline
\end{tabular}

Table.4 Effect of planting dates on quality parameters of red cabbage

\begin{tabular}{|c|c|c|c|}
\hline Treatment & $\begin{array}{c}\text { Anthocyanin } \\
\text { content }(\mathbf{m g} / \mathbf{1 0 0 g})\end{array}$ & $\begin{array}{c}\text { Ascorbic acid } \\
\text { content }(\mathrm{mg} / 100 \mathrm{~g})\end{array}$ & TSS ( ${ }^{\mathbf{0}}$ Brix) \\
\hline D1: $30^{\text {th }}$ September & 108.91 & 35.52 & 7.52 \\
\hline D2: $15^{\text {th }}$ October & 118.83 & 37.68 & 8.54 \\
\hline D3: $30^{\text {th }}$ October & 113.66 & 36.51 & 8.02 \\
\hline SEm \pm & 0.244 & 0.501 & 0.048 \\
\hline CD@ $9 \%$ & 0.719 & 1.479 & 0.141 \\
\hline
\end{tabular}


The favourable climatic conditions prevailing during head formation stage might be attributed to above variations in results. Results of head weight were in line with findings Vipul et al., 2017; Kanase et al., 2018 in broccoli. With respect to head yield per plot, Similar results found in red cabbage (Maria and Krzysztof, 2012) and broccoli (Shapla et al., 2014; Vipul et al., 2017; Vinod et al., 2017; Kanase et al., 2018).

\section{Estimated yield per hectare (q) and dry matter production (\%)}

Significantly higher yield per hectare (338.83 q) and dry matter production (11.24\%) was recorded with $15^{\text {th }}$ October planting, whereas the crop planted on $30^{\text {th }}$ September recorded the lowest estimated yield per hectare (277.70 q) and dry matter production (9.51\%) (Table 3 ). From the above results, it was clear that estimated yield per hectare were significantly affected by planting dates.

The better results were due to the favourable conditions that prevailed during crop growth period and due to optimum level of nitrogen supplied to the crop. Similar findings have been reported in red cabbage (Maria and Krzysztof, 2012), cabbage (Singh et al., 2010; Abed et al., 2015), broccoli (Shapla et al., 2014; Kanase et al., 2018). With regarding dry matter production $(\%)$, similar results were obtained by Abed et al., 2015 in cabbage and Shapla et al., 2014,Vinod et al., 2017 in broccoli.

\section{Quality parameters}

Anthocyanin content (mg/100g), Ascorbic acid content (mg/100g) and TSS $\left({ }^{0} \mathrm{Brix}\right)$

With regarding quality parameters like anthocyanin content $(118.83 \mathrm{mg} / 100 \mathrm{~g})$, ascorbic acid content $(37.68 \mathrm{mg} / 100 \mathrm{~g})$ and TSS $\left(8.54^{\circ}\right.$ Brix $)$ were recorded higher in $15^{\text {th }}$
October planting date $\left(\mathrm{D}_{2}\right)$ compared to all other planting dates. The lowest values for quality parameters were recorded with $30^{\text {th }}$ September planting date $\left(D_{1}\right)$ (Table 4$)$. These results are in conformity with red cabbage (Manasa et al., 2017 and Patel et al., 2017) and broccoli (Vinod et al., 2017; Vipul et al., 2017 and Kanase et al., 2018).

Based on the results obtained in the present investigation, it can be concluded that $15^{\text {th }}$ October planting date proved to be best for getting higher growth, yield, quality and economic returns in red cabbage for coastal Andhra Pradesh.

Significantly higher values were recorded with vegetative parameters like plant height, plant spread and number of leaves. High number of leaves leads to maximum photosynthetic activity and thereby facilitates better translocation of food material to economic parts.

This might have resulted in obtaining higher values with yield parameters like volume of head, head circumference, head weight, yield per plot, yield per hector and dry matter production with the above treatment (D2)and the same was also maintained best quality with respect to anthocyanin content, ascorbic acid content and TSS.

Planting on $30^{\text {th }}$ September planting date (D1) recorded the lowest values for vegetative and yield parameters. The crop transplanted on $30^{\text {th }}$ September planting date (D1) received very high temperature and high humidity which are not conducive for red cabbage. The adverse climatic conditions like higher temperature and relative humidity during the crop growth period restricted the photosynthetic activity and translocation of food materials that might have resulted in poor vegetative growth leading to lesser yields and quality with the above treatment (D1). 


\section{References}

Abed, M. Y., El-Said, E.M and Shebl, E. S. 2015. Effect of planting date and spacing on yield and quality of cabbage (Brassica oleracea var. capitata L.). Journal of Plant Production-Mansoura University, 6(12):2093-102.

Getachew, E., Eba, A. and Wendimu, M. 2016. Growth response of broccoli to different planting date at Jimma South Western Ethiopia, International Journal of Research Granthaalaya, 4(6): 110-18.

Kanase, V. J., Bhosale, A.M. and Shinde, V.N. 2018. Studies on effect of planting dates on growth, yield and quality of broccoli (Brassica oleracea L. var. italica) cv. Green Magic. International Journal of Current Microbiology and Applied Sciences, 6: 8-86.

Lavanya, P., Umajyothi, K., Ushakumari, K., and Sasikala, K. 2015. Effect of dates of planting and nitrogen on growth and yield of cabbage (Brassica oleracea var. capitata. L) cv Radha. The Journal of Research PJTSAU. 43 (4) 12- 15.

Manasa, S.Mukunda Lakshmi, L. Syed Sadarunnisa and Rajasekharam, $\mathrm{T}$. 2017. Effect of plant densities and nitrogen levels on growth and yield of red cabbage (Brassica oleracea var. capitata f. rubra) M.Sc (Hort) Thesis, Dr.Y.S.R. horticulture university, AndraPradesh.

Maria, T. and Krzysztof, S. 2012. The effect of the method and time of seedling production on red cabbage (Brassica oleracea L. ssp. oleracea convar. Capitata (L) Alef. var. capitata L. f. rubra DC.) yield. Acta Agrobotanica, 65(1): 115-22.
More, K. 2006. Response of cabbage (Brassica oleracea var capitata) transplants to nitrogen, phosphorus and potassium nutrition. Desertification submitted for the Master of Science. Department of Plant Production and Soil Science in the faculty of Natural and Agricultural Sciences, University of Pretoria, Pretoria.

National Hotriculture Board. 2018-2019. Indian Journal of Agriculture Data Base. 1-3p. www.nhb.com.

Panse, V. G. and Sukhatme P. V. 1985. Statistical methods for agricultural workers. Indian Council of Agricultural Research. New Delhi.120.

Patel, H. R and Tripathi, S. 2017. Response of Red Cabbage (Brassica oleraceavar. capitata f. rubra) to $\mathrm{N}$ and $\mathrm{P}$ levels under South Gujarat condition. M.Sc (Hort) Thesis, Navsari Agricultural University, Gujarat.

Shapla, S. A., Hussain, M. A., Mandal, M. S. H., Mehraj, H. and Jamaluddin, A. F. M. 2014. Growth and yield of broccoli (Brassica oleracea var. italica) to different planting times. International Journal of Business, Social and Scientific Research, 2(2):95-99.

Singh, B. K., Pathak, K. A., Sarma, K. A. and Manju, T. 2010. Effect of transplanting dates on plant growth, yield and quality traits of cabbage cultivars. Indian Journal of Hill Farming. 23(2): 1-5.

Ullah, A., Islam, M. M., Hossain, M. I., Sarkar, M. D. and Moniruzzaman, M. 2013. Effect of planting time and spacing on growth and yield of cabbage. International Journal Bioresource and Stress Management, 4(2): 182-86.

Vinod, S., Aravindakshan, K. and Bola, P. K. 2017. Effect of sowing date and spacing on growth, yield and quality of 
Broccoli (Brassica oleracea var. Wojciechowska, R. S. and Kołton, A. 2007. italica) var. Green Head. Chemistry Science Review Letter, 6(21), 209-12.

Vipul, P. S., Prasad, V. M. and Deepanshu. 2017. Effect of sowing date on growth and yield of broccoli (Brassica oleracea var. italica). Plant Archives, 17(2):1063-70. The content of some nutrients in red cabbage yield depending on the form of nitrogen fertilizer. 41: 667-71.

Yuan, Y., Chiu, L. and Li, L. 2009. Transcriptional regulation of anthocyanin biosynthesis in red cabbage. Planta, 230: 1141-53.

\section{How to cite this article:}

Abhilash Kavalgi, R. Rajyalakshmi, K. Uma Jyothi and Uma Krishna, K. 2019. Studies on the Effect of Planting Dates on Growth, Yield Components and Quality of Red Cabbage (Brassica oleracea var. capitata f. rubra). Int.J.Curr.Microbiol.App.Sci. 8(12): 2219-2225. doi: https://doi.org/10.20546/ijcmas.2019.812.264 